http://dx.doi.org/10.4314/gjl.v7i1.4

\title{
EVENT AND ACTORS REPRESENTATION IN SELECTED NIGERIAN DAILY NEWSPAPERS
}

\author{
Hameed Tunde Asiru' ${ }^{1}$ Emily A. Ogutu ${ }^{2}$,Daniel Ochieng Orwenjo ${ }^{3}$
}

\begin{abstract}
The 2011 Nigerian presidential election newspaper reports were not just to inform the public about the outcomes of the election. The representations in the newspaper reports were ideological and, by implication, judgmental. The main actors (presidential aspirants), were also represented differently. In this paper, we interrogate some linguistic tools that were used in the ideological presentation of the election and the main social actors. In other words, the paper examines whether the main social actors are included or excluded, genericised or specified; and the level of voice projection accorded to them. The study is anchored on Critical Discourse Analysis framework and it operationalises some aspects of van Leeuwen (2008) socio-semantic model and Hallidayan transitivity system in examining social actor differential representations and process types in the newspaper reports. These linguistic tools (exclusion, inclusion, individualization, assimilation, collectivization, functionalisation, appraisement and voice projection) are very pertinent because they serve as the very foundation on which further context analysis of the discourse could be based. The study observes that social actors representations and voice projection in the data do not only polarize the reportage but also lace it with bias. It also shows that the incumbent president was given more positive representation and voice projection than other aspirants.
\end{abstract}

Keywords: Representation, social actors, CDA

\footnotetext{
${ }^{1}$ Department of English and French, Umaru Musa Yar'adua University, Katsina, Nigeria

${ }^{2}$ Department of English and Linguistics, Kenyatta University, Nairobi, Kenya

${ }^{3}$ Department of Language and Communication Studies, Technical University of Kenya.
} 


\subsection{Introduction}

Apart from the general and elementary views of language as a means of communication and passing information, the negotiation and construction of meaning in our world come under the social functions of language. That is why Gee (2001:1) in his opinion, argues that language is not just about giving and receiving information but to 'scaffold the performance of social activities' and 'to scaffold human affiliation within cultures and social groups and institutions'. These functions are connected because social groups and institutions can shape social activities.

Among the powerful institutions that can shape social activities are the government and the media. The media is generally believed to possess the power to shape the agenda of political actors, just like political actors can also influence what is to be communicated through the media to the public. This role comes to manifest when the media is able to set the stage for political news, manage their agenda, and source and control the information to be communicated to the public (Devaney, 2013). The sourcing and constructing of news are both linked to the opinions and ideology of the media organizations or owners. Similarly, as a result of setting the agenda of political issues and activities, the range of perspectives and arguments are streamlined because the attention of the public would now be focused on the set agenda.

Therefore, the media may have a great impact on political processes such as campaign and elections because it can inform and influence attitudes and perceptions of the electorate. In other words, when media repeatedly exposes text recipients to representations transported in texts, under similar conditions of reception, they may inadvertently or otherwise help to align their representations with that of the text producer and build an advantage for the latter's in-group (Koller, 2012). In the case of elections, this action can consequently influence its outcome. The media, as a social institution, is therefore expected to be neutral and objective in its presentation of political processes such as elections. The objectivity should not be limited only to the processes but should also cover the participants that are involved. However, in Nigeria, media is still being perceived as a ready tool to be used by powerful institutions (Ojo \& Adebayo, 2013). In that case, the media representation of events such as the 2011 presidential election newspaper reports and other political activities in the country may not be neutral but imbued with certain underlying ideologies and power play which, in turn, could impact the outcomes of political events. According to Hampl (2015:56) "the representation of social actors could indicate in what way particular parties, camps, or individuals are portrayed in discourse". It is not out of place to mention that presidential election, being the most important in the country, attracts many interests, hence the scramble for representation by different political actors to determine what is to be communicated in the media. This also lays credence to Devereux's (2009) submission that media is a contested vacuum and not everybody in the 
contest is of equal power. Chilluwa (2011), in his assessment of media power, also asserts that the press may conceal truths that need to be told in some particular representations and may also legitimize a particular label or identity in the interest of certain people or government. The Nigerian political landscape in 2011 and up till date could be said to be a fertile ground where media has enormous power and control over the electorates.

Several studies on social actor representations have been carried out and many of them are anchored on van Leeuwen's system networks of the representation of social actors and Hallidayan Transitivity in Systemic Functional Linguistics (see Post 2009; Sahragard \& Davatgarzadeh 2010; Rashidi and Rasti, 2012; and Amer 2017). In Nigeria, there are few studies that have been conducted which specifically examine representation of social actors in media studies. Such studies include Alo (2008) which takes account of representation of people in the news in the Nigerian print media; Osunsanwo (2016) also examines role allocation in the media representation of participants in electoral discourses in Nigeria. The study centres on the use of activation and passivation to either assign agency or obscure agency to social actors. By implication, some social actors are activated as agents while others are represented as patients. The present study is however different from the previous studies because its focus is on the different linguistic tools that are used in the representation of the presidential aspirants which ultimately show the ideological leaning of the newspaper reportage.

\subsection{Theoretical framework}

This study adopts the Critical Discourse Analysis framework. Critical study of language was motivated as a result of the underestimation of language as a tool in the production, maintenance and change of social relations of power (Fairclough, 1989). The critical approach therefore, aims at increasing consciousness about how language can contribute to the domination of some group over others. These ideas are absent in mainstream linguistics because it (mainstream linguistics) is an asocial way of studying language therefore, it has nothing to say about relationships between language, power and ideology (Fairclough, 1989).

For instance, in Sociolinguistics, though there is a degree of recognition for the social aspect of language, such as how social variables determine language use, little attention is given to language and power. Fairclough further notes that, from a critical perspective, pragmatics is individualistic because action is thought of as emanating from the individual. Pragmatics does not specify the extent to which action/utterance is constrained by and derives its individual identity from social conventions. These are some of the reasons why Fairclough believes that mainstream linguistics is asocial and there is a need for a critical study of language. What then is the foundation of CDA? 
The foundation of CDA can be traced to Critical Linguists' idea of language as an integral part of social processes (Fowler, Hodge, Kress, Trew, 1979). Critical linguists set up an argument for Critical Linguistics based on the assumption that 'there are strong and pervasive connections between linguistic structures and social structures. This possibly led the way for other scholars like Fairclough (1989) and van Dijk (1993) to also view language as a social practice and the need to reveal the dialectical relationship between language and society. Similarly, Strauss and Feiz, (2014) admit the same opinion that, CDA is a broad, interdisciplinary methodological approach to language and society which centres on discourse as social practice. That is, discursive practices are social in nature and social practices are inherently built on and around discourse.

Some of the main approaches that have greatly influenced the framework of CDA are the approaches from its main proponents. These approaches are Fairclough's Dialectical-Relational Approach, Wodak's Discourse-Historical Approach and van Dijk's Sociocognitive Approach. For this study, a socio-cognitive approach is more related to identifying the different representations of the social actors in the Nigerian 2011 presidential elections. What this translates to is a textual construction of the major social actors involved in the elections. According to Koller (2012), 'in socio-cognitive terms, text producers communicate particular SCRs of social actor groups, including beliefs and/or knowledge about them, the attitudes towards and expectations of them that ensue from beliefs and/or knowledge, and the emotions that accrue to them'.

\subsection{Methodology}

For this study, a multistage sampling technique was adopted. This is because it involves different stages owing to the large number of daily newspapers in Nigeria. Also, each paper has several news articles and there is therefore the need to narrow down our selection to the needed news articles. As a result, the initial stage had to do with random sampling of two national daily newspapers from each of the most populated states in the zones; Lagos, Kano, Benue, Bauchi, Rivers and Anambra. The outcome gave us twelve national daily newspapers. The second stage was to random sample one newspaper from each city. These newspapers were selected from the national dailies that were kept by the national libraries in each of the states selected for this study. The total numbers of the newspapers are six. The last stage adopts a non-probability purposive random sampling whereby two (2) election news articles (the lead articles and one other news article) were selected from the newspapers. The total sample consists of (twelve) news reports of about six thousand and nine (6009) words selected from six (6) different newspapers in the country. The thematic focus of the all the sampled articles is an account of the voting processes, counting and the announcements of results by some electoral commissioners from some states of the federation. The selected newspapers are: Punch, Nigerian Tribune, 
The Guardian, New Nigerian, Daily Trust and This Day. The table below indicates the number of words in each of the articles used.

\begin{tabular}{|c|c|c|c|c|c|c|}
\hline $\begin{array}{c}\text { Sources of } \\
\text { the News } \\
\text { Articles }\end{array}$ & Punch & $\begin{array}{c}\text { Nigerian } \\
\text { Tribune }\end{array}$ & $\begin{array}{c}\text { The } \\
\text { Guardian }\end{array}$ & $\begin{array}{c}\text { New } \\
\text { Nigerian }\end{array}$ & $\begin{array}{l}\text { This } \\
\text { Day }\end{array}$ & $\begin{array}{c}\text { Daily } \\
\text { Trust }\end{array}$ \\
\hline $\begin{array}{c}\text { Number of } \\
\text { Words }\end{array}$ & 421 & 561 & 160 & 811 & 419 & 432 \\
\hline Subtotal & $\mathbf{8 0 8}$ & $\mathbf{8 7 1}$ & $\mathbf{1 0 7 0}$ & $\mathbf{1 4 2 6}$ & $\mathbf{1 1 9 2}$ & $\mathbf{6 4 2}$ \\
\hline
\end{tabular}

\subsection{Findings}

\subsection{Representation of the social actors}

The representation of social actors is not arbitrary or trivial (Coesemans, 2013). It contributes to the creation of a frame of interpretation. This is important because it helps in the search for patterns of unquestioned meaning and ideological aspects of news discourse. This is because social actors may have 'inclusion or exclusion' (van Leeuwen, 2008:29) patterns in any representation depending on the interests and purposes of such representation. When social actors are excluded in news reports, it may be for strategic reasons or it may be assumed that readers are already familiar with such details or that such details are irrelevant. The same opinion is held by Sahragard (2010:76) that 'some exclusions may be innocent, details which readers assume to know already or which are deemed irrelevant to them; others impose certain ideologies on the readers...' Therefore, ideology is at stake when social actors are excluded based on strategic reasons. In a similar perspective, 'social actors can be utilized for the purposes of being an instigator of action, an agent of action, a beneficiary of action or one affected by action (Van Leeuwen, 2008:7). In case of exclusion, the actors are either suppressed which makes them totally absent from the news reports or they are backgrounded, that is they are not mentioned but could be inferred as a result of the shared background knowledge. However, newspaper reports of a presidential election may not record any case of exclusion, either suppression or backgrounding.

The representation strategies can be in the form of 'individualization and assimilation' (van Leeuwen 2008: 37). In CDA, 'individualization and assimilation' strategies are of paramount importance because our society places much significance on personality and group affiliations. Individualization occurs in news discourse when social actors are referred to as individuals taking cognizance of their personalities in the society. On the contrary, assimilation (collectivization and aggregation) occurs when social actors are represented as groups. 
In this study, we will narrow our social actors' representation to the major contenders for the presidential position. They are the ones mentioned in all the news reports; Jonathan, Buhari, Ribadu and Shekarau.

Consider the following examples on individualization:

a) Jonathan won convincingly.

b) Jonathan maintained a comfortable lead.

c) Jonathan still clinched the mandatory 25 percent, (Guardian April 18, 2011).

The above examples show Jonathan being referred to as an individual personality. Also, he is represented the most, quantitatively, in the headlines. Out of the 12 headlines, Jonathan is mentioned 8 times. He is represented as a distinct individual while other contestants are marginalized and assimilated as 'others' in the headlines.

Also, the form of assimilation that is present in the data is 'collectivization' and it occurs in form of party affiliation. This is presented in the examples below:

d) The PDP led comfortably in...;

e) The PDP defeated other political parties;

f) The PDP also took its winning magic to...;

g) PDP had a smooth sail..;

h) PDP also won with a wide margin...; (The Punch, Monday, April 18, 2011)

Other political parties are represented as follows:

i) ACN trailed behind...;

j) CPC suffered defeat...;

k) CPC got...; ACN had...; (The Punch Monday April18, 2011)

In the news reports, 'collectivization' helps to positively portray the Goodluck Jonathan's party (PDP). The positive representations can be found in the form of verbs used in examples $d-h$. For the opposition parties, they are collectivized with neutral verbs ( $\mathrm{got}, \mathrm{had}$ ) and verbs that portray them as losers (trailed, suffered).

Another strategy for representing social actors in news reports is referred to as 'functionalization' (Van Leeuwen, 2008); a subdivision of categorization. Functionalization means the 'representation of social actors in terms of something they do, an occupation or role in society' (Coesemans, 2012: 190). It deals with the ways the main contenders are introduced in the news reports. Consider the following examples from the data: 
l) Early results from some polling centres across the country showed President Goodluck Jonathan and Major-General. Muhammadu Buhari (retd) in a tight race in the presidential election... (Sunday Punch April 17, 2011).

m) .....President Goodluck Ebele Jonathan of the People's Democratic Party PDP had won this year ['s] presidential election...

n) His closest rival, General Muhammadu Buhari of Congress for Progressive Change (CPC)... (Daily Trust, Monday April 18, 2011)

In the above sentences $l$ - $n$, Goodluck Jonathan is introduced as the 'President' owing to his current political office while Muhammadu Buhari is represented as 'MajorGeneral' because of his past position as a former Head of State. This representational strategy may not be neutral because it may remind the people the roles the Military played in Nigerian Democracy in the past with several coups which plunged the country into civil war and ethnic conflicts. Referring to Muhammadu Buhari as 'General', could trigger people's consciousness to his antecedence. (He aborted the Second Republic which was headed by President Shehu Shagari) Therefore, for him to be contesting for the same position under a democratic setting might presuppose that he is a dictator, and that can inform a kind of apathy from the press. If compared to what happened in the 1999 and 2003 presidential elections where Olusegun Obasanjo, also a General in the army, contested for the post of presidency and won, the scenario differs. Olusegun Obasanjo was fondly called 'Chief' during and after the election; perhaps to make Nigerians forget the roles of the military in the June 12, 1993 election which was annulled by the then Military Head of State.

Finally, 'functionalization' may have evaluative connotations which may be ideological and when this happens, it is termed 'appraisement' (Leeuwen, 2008). Let us look at the example below:

o) Aconfident President Goodluck Jonathan... (Sunday Punch April 17, 2011).

The example above shows a positive representation of Goodluck Jonathan. The example shows that he is being appraised as 'confident', an adjective that evaluates him to be a better candidate and possibly the most preferred. In contrast, the newspapers are all silent in terms of appraisement of the other major contestants. More importantly, this form of appraisement is positive compared to evaluation that portrays the negative face of Goodluck Jonathan. 


\subsection{Transitivity in the Newspaper Headlines}

Transitivity system, according to Halliday (1985), is explained in terms of processes and participants. It is a semantic system that explains the world of experience into a set of process types (Wang, 2010). Transitivity is also seen as a grammatical system by which ideational meaning is represented in the clause by the type of process and participants which accompany the process (O'Halloran, 2003: 17). Performing a transitivity analysis requires the identification of certain patterns in the use of the processes. Participants and Processes analysis is a form of representation with ideological clues for analysts. This is because the several semantic choices available to a speaker in recounting his experience of the world and the participant types can be manipulated. When the patterns of transitivity are identified, meanings which are emphasized in terms of the experiential, relational and expressive can be identified.

The processes include 'material, mental, relational, verbal, behavioural and existential.' The selection between these process types may highlight or background agency and consequently, leave the attribution of causality and responsibility unclear (Min, 1997). Relevant in the present study are material, mental and relational processes. Consider some examples of the processes below:

Material processes are concerned with the process of 'doing' something. It portends that an action has been done by some entity and it is realized through an action verb, an actor and the goal of the action. An actor is the logical direct subject, and a goal is the logical direct object, usually a noun or a pronoun (Zhuanglin, 1988). He (actor) .... concluded (mental process) that Nigerians (goal) had shown (material process) more interest and commitment in the 2011 elections (goal) than they (actor) did (material process) in previous ones (goal).

Mental processes are processes of feeling, thinking and seeing. There are two participants involved here, the Senser and the Phenomenon. Mental process does not carry out action but it represents inner feelings of 'perception (hearing), affection (fearing) and cognition (knowing)'. He (Senser) recalled (mental process) his involvement in elections conducted in 1999, 2003 and 2007 (Phenomenon).

Relational process is a process of being. It establishes relationships between two entities, and it can be divided into two: identifying relation and attributive relation. Attributive relation shows the qualities that an entity possesses and it has a 'carrier', 'process' and 'attribute' while identifying relation means that an entity and another is uniform and it has identified, process and identifier. Jonathan, Buhari (carrier) ((are) process) in tight race (attributes). 
Tables 1 and 2 below present the material and relational processes in the headlines of the news reports.

Table 1: Material Processes in the Headlines

\begin{tabular}{|l|l|l|}
\hline \multicolumn{1}{|c|}{ Actor } & \multicolumn{1}{c|}{ Processes } & \multicolumn{1}{c|}{ Goal } \\
\hline Labour & rates, lauds (Material) & election, voters \\
\hline Hurricane Jonathan & knocks out (Material) & Buhari, others \\
\hline Jonathan & cruises, reaches out (Material) & victory, opponents \\
\hline Jonathan & floors (Material) & Buhari, Ribadu \\
\hline Jonathan & sweeps (Material) & presidential poll \\
\hline $\begin{array}{l}\text { Bakare, } \\
\text { IBB, Okotie }\end{array}$ & laud (Material) & peaceful election \\
\hline Jonathan & wins (Material) & the big prize \\
\hline Jonathan & sweeps (Material) & South-West \\
\hline
\end{tabular}

Table 2: Relational Processes in the Headlines

\begin{tabular}{|l|l|l|}
\hline \multicolumn{1}{|c|}{ Carrier } & \multicolumn{1}{c|}{ Process } & \multicolumn{1}{c|}{ Attribute } \\
\hline Presidential Poll & & Massive turnout, generally peaceful \\
\hline $\begin{array}{l}\text { Trend in Nigeria } \\
\text { Politics }\end{array}$ & $($ is $)$ & wind of change \\
\hline Jonathan, Buhari & (are) & in tight race \\
\hline Jonathan! & Hail & to the Chief! \\
\hline
\end{tabular}

In the tables above, material and relational processes feature in the news reports. There is no instance of mental process in the headlines. Generally, transitivity offers a systematic choice among different processes. The presence of material and relational processes in textual configuration of the newspaper reports' headlines suggest some choices out of many other transitivity processes. There are many ways of capturing or representing experience in language. The material and relational processes are privileged or preferred to others in the headlines. These choices are perhaps strategically motivated options from other possible processes.

Part of the possible interpretation for the motivation for representing experiences using material and relational processes is to examine the explicit or implicit agent role and the circumstances associated with the processes. In the tables above, in relation to circumstances associated with the process, the action of 'winning' is mostly attributed to Jonathan and that is why it is conspicuously placed as the main actor in the headlines. The attribution of agency to Jonathan in seven places out of twelve headlines is not 
$\overline{\text { ideologically neutral. Meanwhile, there is a case where the agency attribution was shared }}$ in the headlines, such as 'Jonathan, Buhari in a tight race'. There is also an instance of agency deletion in the headline 'Violence, Fraud mar presidential poll'. Similarly, having more material process mostly favoured in the headlines has underlying agenda; perhaps to concretize the action of the main actor and consequently portray him as the winner even when the results have not been announced.

To further examine the processes in the news reports, we decide to include the lead paragraphs since we could not examine the whole articles. We believe that lead paragraphs mostly contain the main message in an article. The lead paragraphs are numbered serially from 1-12.

\subsubsection{Transitivity in the Lead Paragraphs of the Newspaper Reports}

1. President Goodluck Jonathan, the presidential candidate of the PDP, broke into the stronghold of the opposition CAN, in the South-West, in yesterday's presidential election. (Sunday Vanguard, April 17, 2011)

\begin{tabular}{|l|l|l|}
\hline \multicolumn{1}{|c|}{ Actor } & \multicolumn{1}{|c|}{ Material process } & \multicolumn{1}{c|}{ Goal } \\
\hline $\begin{array}{l}\text { President Goodluck } \\
\text { Jonathan, the } \\
\text { presidential candidate } \\
\text { of the PDP }\end{array}$ & broke into & $\begin{array}{l}\text { the stronghold of the opposition } \\
\text { CAN, in the South-West, in } \\
\text { yesterday's presidential election }\end{array}$ \\
\hline
\end{tabular}

2. Results of Saturday's presidential election so far released by the Independent Electoral Commission on Sunday showed President Goodluck Jonathan having an unassailable lead (The Punch, April 18, 2011).

\begin{tabular}{|l|l|l|}
\hline \multicolumn{1}{|c|}{ Actor } & Material process & \multicolumn{1}{c|}{ Goal } \\
\hline $\begin{array}{l}\text { by the Independent } \\
\text { Electoral } \\
\text { Commission }\end{array}$ & $\begin{array}{l}\text { so far released/ } \\
\text { showed/ having }\end{array}$ & $\begin{array}{l}\text { Results of Saturday's presidential } \\
\text { election/President Goodluck Jonathan/ } \\
\text { an unassailable lead }\end{array}$ \\
\hline
\end{tabular}

3. President Goodluck Jonathan of the People's Democratic Party, (PDP) has won last Saturday's presidential election, defeating his closest rivals Major-General Muhammadu Buhari of the Congress for Progressive Change, (CPC) and Mallam Nuhu Ribadu of the Action Congress, (ACN). (Nigerian Tribune, April 18, 2011) 


\begin{tabular}{|c|c|c|}
\hline Actor & Material process & Goal \\
\hline $\begin{array}{l}\text { President Goodluck } \\
\text { Jonathan of the } \\
\text { People's Democratic } \\
\text { Party, (PDP) }\end{array}$ & has won & $\begin{array}{l}\text { last Saturday's presidential election, } \\
\text { defeating his closest rivals, Major- } \\
\text { General Muhammadu Buhari of the } \\
\text { Congress for Progressive Change, } \\
(\text { CPC) and Mallam Nuhu Ribadu of } \\
\text { the Action Congress, (ACN). }\end{array}$ \\
\hline
\end{tabular}

4 With results officially declared by state collation officers in 35 states and the Federal Capital Territory, (FCT) last night, President Goodluck Ebele Jonathan of the People's Democratic Party, (PDP) had won this year's presidential election with 21.5 million votes and a quarter of the votes in all of them except Kano, Borno and Bauchi States. (Daily Trust, April 18, 2011)

\begin{tabular}{|l|l|l|}
\hline \multicolumn{1}{|c|}{ Actor } & \multicolumn{1}{|c|}{ Material process } & \multicolumn{1}{c|}{ Goal } \\
\hline $\begin{array}{l}\text { by state collation } \\
\text { officers/President } \\
\text { Goodluck Ebele }\end{array}$ & officially declared/ & $\begin{array}{l}\text { With results/ this year's presidential } \\
\text { election with 21.5 million votes and a }\end{array}$ \\
$\begin{array}{l}\text { Jonathan of the } \\
\text { People's Democratic }\end{array}$ & & $\begin{array}{l}\text { quarter of the votes in all of them } \\
\text { except Kano, Borno and Bauchi } \\
\text { Party, }(\text { PDP) }\end{array}$ \\
\hline
\end{tabular}

5 Congress for Progressive Change, CPC presidential running mate, Pastor Tunde Bakare, former President Olusegun Obasanjo and former military president, Ibrahim Babangida, weekend, joined several other Nigerians in commending the smooth conduct of the presidential elections by INEC (Vanguard, April 18, 2011).

\begin{tabular}{|l|l|l|}
\hline \multicolumn{1}{|c|}{ Actor } & \multicolumn{1}{|c|}{ Material process } & \multicolumn{1}{|c|}{ Goal } \\
\hline $\begin{array}{l}\text { Congress for Progressive Change, } \\
\text { CPC presidential running mate, }\end{array}$ & Joined/commending & $\begin{array}{l}\text { the smooth conduct of the } \\
\text { presidential elections by } \\
\text { Pastor Tunde Bakare, former } \\
\text { President Olusegun Obasanjo and } \\
\text { former military president, Ibrahim } \\
\text { Babangida, }\end{array}$ \\
\end{tabular}

6. Dr. Goodluck Jonathan is the president-elect only awaiting official confirmation from the (INEC) today, going by the results that were announced yesterday by the Resident 
Electoral Commissioners (RECs) in the 36 states and the Federal Capital Territory, (FCT) (This Day, April 18, 2011).

\begin{tabular}{|c|l|l|}
\hline Carrier & \multicolumn{1}{|c|}{ Process } & \multicolumn{1}{c|}{ Attributes } \\
\hline Dr. Goodluck Jonathan & Is & the president-elect \\
\hline
\end{tabular}

\begin{tabular}{|l|l|l|}
\hline \multicolumn{1}{|c|}{ Actor } & \multicolumn{1}{|c|}{ Material process } & \multicolumn{1}{c|}{ Goal } \\
\hline $\begin{array}{l}\text { by the Resident } \\
\text { Electoral }\end{array}$ & $\begin{array}{l}\text { only awaiting/that } \\
\text { were announced }\end{array}$ & $\begin{array}{l}\text { official confirmation from the (INEC) } \\
\text { today }\end{array}$ \\
$\begin{array}{l}\text { Commissioners } \text { (RECs) } \\
\text { in the 36 states and the }\end{array}$ & \\
$\begin{array}{l}\text { Federal Capital } \\
\text { Territory }\end{array}$ & & \\
\hline
\end{tabular}

7. Early results from some polling centres across the country showed President Goodluck Jonathan and Maj-Gen. Muhammadu Buhari (retd.) in a tight race in the presidential election conducted by the Independent National Electoral Commission across Nigeria on Saturday. (Sunday Punch, April 17, 2011)

\begin{tabular}{|c|c|c|}
\hline Actor & Material process & Goal \\
\hline $\begin{array}{l}\text { President Goodluck } \\
\text { Jonathan and Maj-Gen. } \\
\text { Muhammadu Buhari (retd) } \\
\text { the Independent National } \\
\text { Electoral Commission } \\
\text { across Nigeria on Saturday }\end{array}$ & $\begin{array}{l}\text { showed/ } \\
\text { conducted }\end{array}$ & $\begin{array}{l}\text { Early results from some polling } \\
\text { centres across the country }\end{array}$ \\
\hline
\end{tabular}

8. With the collation of the Presidential election results which took place last Saturday still going on last night in Abuja, the ruling People's Democratic Party appeared to have swept the polls across the country.

\begin{tabular}{|l|l|l|}
\hline \multicolumn{1}{|c|}{ Senser } & \multicolumn{1}{|c|}{ Mental process } & \multicolumn{1}{c|}{ Phenomenon } \\
\hline $\begin{array}{l}\text { the ruling People's } \\
\text { Democratic Party }\end{array}$ & $\begin{array}{l}\text { appeared to have } \\
\text { swept }\end{array}$ & the polls across the country \\
\hline
\end{tabular}


9. The Independent National Electoral Commission, (INEC) appears to have overcome most of the logistic lapses witnessed during the National Assembly elections... (New Nigerian, April 17, 2011)

\begin{tabular}{|l|l|l|}
\hline \multicolumn{1}{|c|}{ Senser } & \multicolumn{1}{|c|}{ Mental process } & \multicolumn{1}{c|}{ Phenomenon } \\
\hline $\begin{array}{l}\text { The Independent National } \\
\text { Electoral Commission, } \\
\text { (INEC) }\end{array}$ & $\begin{array}{l}\text { appears to have } \\
\text { overcome }\end{array}$ & $\begin{array}{l}\text { most of the logistic lapses } \\
\text { witnessed during the } \\
\text { National Assembly elections }\end{array}$ \\
\hline
\end{tabular}

10. This is the tune played to herald the appearance of the United States Presidents at any public occasion and its first line is 'Hail to the Chief we have chosen for the nation'. The original line of this song, written by Sir Walter Scott was 'Hail to the chief who in triumph advances...'

\begin{tabular}{|l|l|l|}
\hline \multicolumn{1}{|c|}{ Actor } & \multicolumn{1}{|c|}{ Material process } & \multicolumn{1}{c|}{ Goal } \\
\hline $\begin{array}{l}\text { This is the tune/its first line/ } \\
\text { The original line of this song/ } \\
\text { Sir Walter Scott }\end{array}$ & $\begin{array}{l}\text { Played to herald/is/ } \\
\text { written/was }\end{array}$ & $\begin{array}{l}\text { the appearance of the United } \\
\text { States Presidents at any } \\
\text { public occasion/ 'Hail to the }\end{array}$ \\
& & $\begin{array}{l}\text { Chief we have chosen for the } \\
\text { nation'/ 'Hail to the chief } \\
\text { who in triumph advances...' }\end{array}$ \\
\hline
\end{tabular}

11. The presidential election in which Nigerians yesterday decided the fate of President Goodluck Jonathan of the People's Democratic Party (PDP), General Muhammadu Buhari of the Congress for Progressive Change (CPC), Malam Nuhu Ribadu of the Action Congress of Nigeria (ACN), Governor Ibrahim Shekarau of the All Nigeria People's Party (ANPP) and about sixteen others, was marred by violence, in the form of a bomb blast, and mob attacks.

\begin{tabular}{|l|l|l|}
\hline Actor & Material process & Goal \\
\hline $\begin{array}{l}\text { The presidential } \\
\text { election... and sixteen others }\end{array}$ & was marred & $\begin{array}{l}\text { by violence, in the form of a } \\
\text { bomb blast, and mob } \\
\text { attacks. }\end{array}$ \\
\hline
\end{tabular}

12. The Presidential election yesterday recorded an impressive turn out of electorate in the Southern part of Kaduna metropolis with the commencement of verification exercise as scheduled. 


\begin{tabular}{|l|l|l|}
\hline \multicolumn{1}{|c|}{ Actor } & \multicolumn{1}{|c|}{ Material process } & \multicolumn{1}{|c|}{ Goal } \\
\hline The Presidential election & Recorded & $\begin{array}{l}\text { an impressive turn out of } \\
\text { electorate in the Southern } \\
\text { part of Kaduna metropolis } \\
\text { with the commencement of } \\
\text { verification exercise as } \\
\text { scheduled. }\end{array}$ \\
\hline
\end{tabular}

The analysis above on lead paragraphs reveals the preponderance of material process than other processes. Material process, as it is, and the representation of Jonathan as the 'Actor' further indicates that the actions represented in them help to concretize the victory for Goodluck Jonathan. The quantification of the processes is presented in Figure 1 .

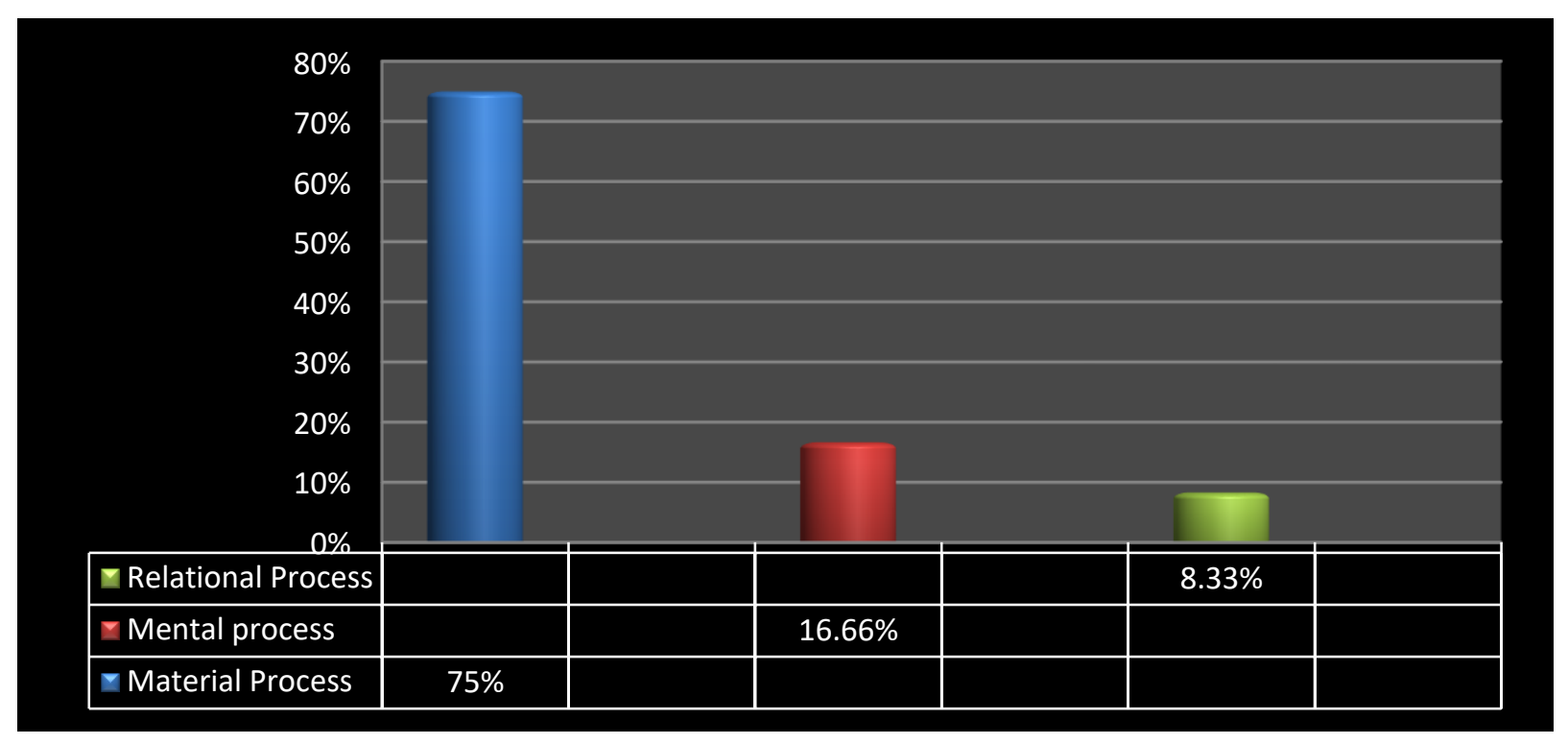

\section{Figure 1: Processes in the Lead Paragraphs of the Newspaper Reports}

The chart above indicates that material process in the lead paragraphs is $75 \%$, followed by mental process $16.66 \%$ and relational process with $8.3 \%$. The result is similar to the processes in the headlines. Material process is predominant; hence it performs a similar function of highlighting the agent role. 


\subsection{Voice Projection}

In news discourse, journalists are saddled with the responsibility of determining what to be included or excluded in their reportage. In the process, some actors are given more voice projection than others. Voice projection comes in the form of quotation. It gives the readers the opportunity of being informed about what was said by the actors and the context of the utterance. It also deals with how voice is carried to an audience. While some actors are positively represented, others are negatively contextualized by denying them voice projection.

According to Fowler (1991) quotation is a discursive mechanism that is potentially a powerful ideological tool for manipulating readers' perception and interpretation of events and issues in news reports. Despite being a powerful ideological tool, the purposes it serves, either direct or indirect quotation, in news reports vary from adding credibility, personalising a story, inviting readers to be identified with the quoted individual or distancing the writer from the propositions made in the quotation (Gravells, 2014). This idea of quotation is a proto-typical form of what Fairclough (1995) refers to as direct discourse, hence (DD) in discourse representation.

Fairclough is also of the view that discourse representation has tendencies of reflecting the ideological affinities of the producers of news. His conception of discourse representation is influenced by Leech and Short (1981) who examined how speech and thoughts are represented in novels. They name their model as speech presentation and it is divided into five categories, namely: Narrative Report of Speech Action, (NRSA); Indirect speech, (IS); Free Indirect Speech, (FIS); Direct Speech, (DS); and Free Direct Speech, (FDS).

Let us look at the following instances and patterns of voice projection in the data. The examples show the level of voice projection associated with the major actors in the election namely: President Jonathan and General Buhari.

a. He (Jonathan) said, "I'm indeed happy that we are consolidating democracy. Democracy must be built on a solid foundation. Foundation of which democracy is built on is the power of the ballot paper. If the ballot paper means nothing, then there is no democracy. Nigeria is now experiencing true democracy where we the politicians have to go to the people because the power belongs to the people."

$b$. "The power does not belong to the politicians. It belongs to the people as expressed in ballot boxes. People have shown high degree of commitment so you can describe it as a new dawn in our political evolution."

c. "I promised I would contest the election as an incumbent president and I would not influence the electoral process. And that has been demonstrated in previous elections." 
d. "I don't know whether it will go into run-off. But I pray that we don't go into such because of its implications. Nigeria is a very big country to conduct another round of election."

$e$. "If I lose, I will leave because that is what we are talking about."

f. "One of such planes came earlier this (Saturday) morning to Katsina airport, and our people were driven away from the airport before the consignment was off loaded and driven straight to the Government House," he said. (Buhari) (Sunday Punch, April 17, 2011)

In the above quotations, one of the aspirants (Jonathan) was quoted extensively in five places, from example ' $a$ ' to ' $e$ ' while the other aspirant (Buhari) was quoted just once. Jonathan's quotations are extensive because they are not short quotations or what Bell (1991) calls 'scare quotes' where few words are quoted to emphasise the speaker's point. Buhari was quoted once with minimal quote. This possibly portends that Buhari is not well quoted in the news reports. According to Kuo (2007:285) 'the relationship between quotation and power relations is found not only in who gets quoted but also in how quotation is presented'. That is, the social position or power determines how well a person is quoted because a powerful person is quoted more verbatim than the less powerful person. Ideologically too, the extended quotations may give salience to the message rather than the actor.

The quotations from $a-e$ are all positive representation of the actor (Jonathan) while the only one attributed to the main opponent is a negative representation. Therefore, we could say that all the positive quotations attributed to Jonathan resemble what Fairclough (2000) refers to as the 'image-making rhetoric'. This is an attempt to self-portray oneself in positive light and it can be seen as a characteristic of a new-generation politician. In the quoted samples, Jonathan tries to self-portray himself positively. The choice of selecting those particular positive accounts for quotation by news writer may not be neutral but to illuminate positive portrayal of Jonathan.

On the contrary, the other aspirant was not given much speech projection by allowing him to speak for himself through an extended direct quote like Jonathan; he was given minimal direct quote in the data. The ideological implication of this strategy is to foreground the actor rather than the message and this can also be a way of marginalizing him. For instance, van Dijk's (1991) study shows that media often marginalize ethnic minorities in the coverage of ethnic affairs through its choice of sources and quotation patterns. Teo (2000) also supporting this idea posits that quotation patterns further make the less privileged powerless because their opinions are less quoted. Therefore, Buhari as the main opponent is marginalized or suppressed in terms of speech projection which could have made him more relevant in the news reports. 
The Figure 2 below shows the percentages of quotations by the main presidential aspirants in the data.

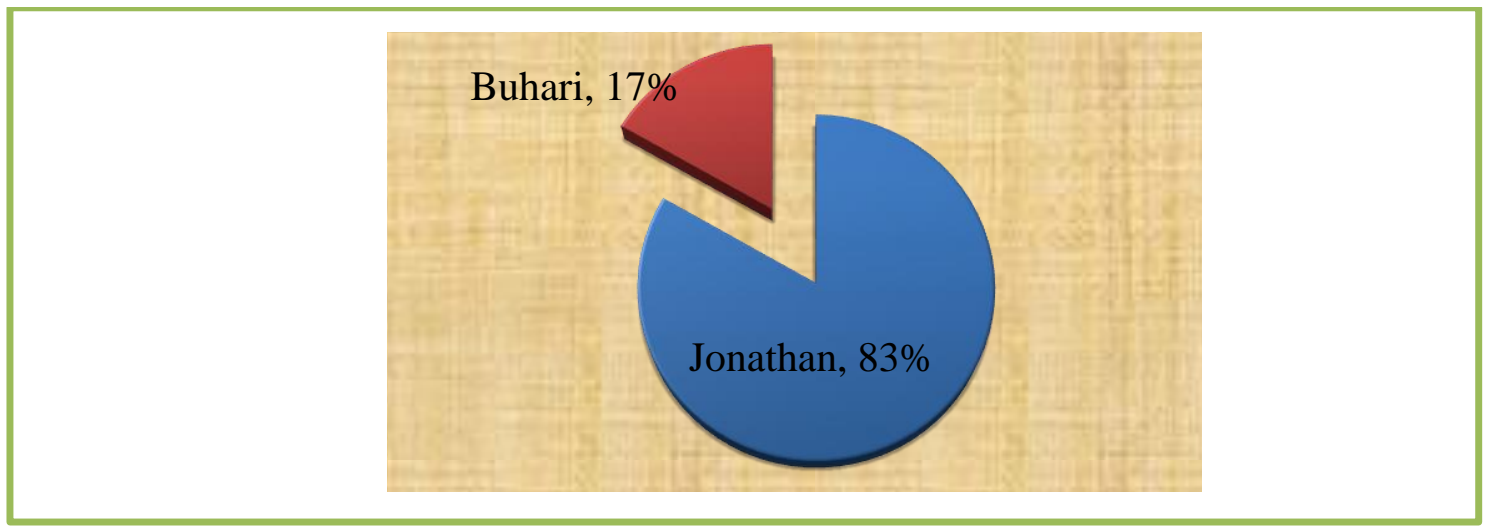

\section{Figure 2: Voice Projection Percentages in the Newspaper Reports}

The figure above indicates that Jonathan was more quoted than Buhari. What makes Buhari to be quoted less than Jonathan could be as a result of what the reporter wants or his interest. Kuo (2007: 281) opines that 'the choice of quotation patterns is by no means objective or neutral and presentation of speech in the news tend to be loaded with ideological biases'. Even though quotation ensures accuracy of what the quoted person said and to distance the journalist from the opinions quoted, it has power potentials that journalists can wield. To Broersma (2010), well-chosen quotations and the attribution of speech can increase the credibility of stories and journalism's claim to truth. This further supports the idea that quotations could be selective depending on the focus or interest of the writer. Their selective quotations may represent the parts of speech which they deem significant and which serve their ideological aims.

A similar position is held by Davis (1985) that the pattern of quotation in news discourse is not neutral but mediated and loaded with ideological bias. This is borne out of the fact that the same words used by a newsmaker can be interpreted differently by different reporters based on their different social affiliations and diverse views.

A study conducted by Ghannam (2011: 3) concludes that the placement of quotation in a discourse is also important. He is of the opinion that when a quote is presented at the beginning of news reports, it highlights the information and presents it as important. On the other hand, when quotation is presented at the end of news reports, it would be 'less noticeable and therefore carry less weight'. This decision of placement depends on the ideology of the newspapers. In the present study, though we did not consider the placement of the quotations, we believe that the choice of placement of 
quotation will perform the same ideological function like how and how often the actors are quoted as shown in this study.

\subsection{Conclusion}

Studies in media and political discourses have been conducted by many researchers. Alo and Ogungbe (2009) argue that 'language, in news reports, is not a mere instrument of communication but it is imbued with power; it is action-oriented; it has the ability to influence or control reader's [sic] thoughts and actions'. In this study, we have been able to detect how media stance or bias is embedded in social actor's representation through some aspects of van Leeuwen's actor representation model. Thus, the electoral discourse was shaped to have some ideological influence on the readers of the newspaper concerning the outcomes of the elections. This finding further supports Makamani (2010) who examines hate language in political discourse in Zimbabwe. He contends that language can be used for manipulative purposes, for image building and forging identities. The identity so forged in the present study is to discursively portray a particular aspirant as winner while others are presented as losers. Idiagbon (2010) also examines the language use in selected Nigerian Presidential election campaign speeches, using the framework of CDA. The study reveals the strategies used in manipulating linguistic facilities in order to win the mandate of the electorates. The strategies include many concepts from CDA, such as topicalisation, mood system, passivisation, presupposition, connotation, tone and style. The study discovers that campaign speeches are reflections of many ideological differences because of party politics, individual interests, emotions and sentiments. This further underscores the importance of CDA in the analysis of media and political discourses.

In the present study, a particular group is presented positively while others are represented negatively. This was done by polarizing the arguments in the newspaper reports as evident in the analysis. The analysis on the social actors' representation indicates that the representation was biased because the ruling party and President Jonathan were more favourably portrayed in the newspaper reports than others. The social actors that are given more inclusion and voice projection are, in most cases, individualized and positively presented. On the other hand, other social actors that are excluded in the headlines and represented with minimal voice projections are assimilated in the newspaper reports. This clearly shows the level of bias in the representation of the social actors. Also, the prevalence of material process in the representation of Jonathan as the 'Actor' further indicates that the actions represented in them help to concretize the victory for Goodluck Jonathan. 


\subsection{References}

Abdullahi-Idiagbon, M. S, 2010. Language use in selected Nigerian Presidential election campaign speeches: A critical discourse analysis perspective. Journal of the Nigeria English Studies Association (JNESA), 13(2), 30-44.

Alo, Moses \& Ogungbe, Ebenezer. O. 2012. Lexicalisation in news stories of some Nigerian National newspapers. LUMINA, 23(2), 1-19

Alo, Moses A., 2008. The representation of people in the news in the Nigerian print media. In Akin, Odebunmi, Rotimi, Taiwo \& Akin, Adetunji, eds., Perspectives on media discourse. Germany: LINCOM EUROPA. Pp.....00-00

Amer, Mohammed. 2017. Critical discourse analysis of war reporting in the international press: The case of the Gaza war of 2008-2009. Palgrave Communications 3(13), $1-11$

Bell, Allan. 1991. The language of news media. Oxford, UK: Blackwell.

Broersma, Marcel. 2010, Journalism as performatives discourse: the importance of form and style in journalism. In Verica Rupar, ed., Journalism and sense-making: reading the newspaper. Cresskill, NJ: Hampton Press. pp.15-35.

Chiluwa, Innocent. E. 2011. Media representation of Nigeria's Joint Military Task Force in the Niger Delta crisis. International Journal of Humanities and Social Science, 1(9), 197-208.

Coesemans, Roel. 2013. Tribal Politics, Tribal Press, Plural Contexts? Pragmatic analysis of news discourse on Kenyan crisis. IC - Revista Científica de Información y Comunicación, 179-200

Devaney, Haley. 2013. Perceptions of media bias: viewing the news through ideological cues. A Senior Honor Thesis, University of California, San Diego.

Eoin Devereux. 2009. Media studies: key issues and debates. London: Sage Publications.

Fairclough, Norman. 1989. Language and power. London: Longman.

Fairclough, Norman. 1992. Discourse and Social Change. Cambridge: Polity Press.

Fairclough, Norman. and Wodak, Ruth. 1997. Critical discourse analysis. In Teun. A. van Dijk ed., Introduction to discourse analysis. London: Sage. Vol. 2, pp. 258-284.

Fowler, Roger. \& Hodge, B. 1979. Critical linguistics. In Roger Fowler et al, eds., Language and Control. London: Routledge and Keegan Paul. pp. 185-213.

Fowler, Roger. 1991. Language in the News: Discourse and Ideology in the Press. London \& New York: Routledge.

Gee, James P. 2001. An Introduction to Discourse Analysis: Theory and Method. Retrieved from Taylor \& Francis e-Library. 
Ghannam, Nada. 2011. Newspaper ideology: A critical discourse analysis of an event published in six Lebanese newspapers. University of Witwatersrand, South Africa. M. A Thesis.

Halliday, Michael. A. K. 1985. Introduction to functional grammar. London: Edward Arnold.

Huddleston, Rodney. Geoffrey K. Pullum. 2002. The Cambridge Grammar of the English Language. Cambridge, UK: Cambridge University Press.

Kendall, Gavin. 2007. What is critical discourse analysis? Ruth Wodak in conversation with Gavin Kendall. Forum: Qualitative Social Research, 8(2), Art. 29, Retrieved from http://www.qualitative-research.net/fqs-texte/2-07/07-2-29-e.htm

Leeuwen, Van. 2008. Discourse and Practice: New tools for Critical Discourse Analysis. New York: Oxford University Press, Incorporation.

Li, J. (2013). Translating Chinese political discourse: A functional-cognitive approach to English Translations of Chinese political speeches. University of Salford, Salford, UK. Ph.D. Thesis.

Makamani, Rewai. 2010. Brown is saying nonsensical things, much more idiotic than Blair: An analysis of hate language in political discourse used in Zimbabwe. In Daniel, Ochieng Orwenjo \& John Obiero. Ogone eds., Language and politics in Africa: Contemporary issues and critical perspectives. Newcastle: Cambridge Scholars Publishing. pp. 2-25.

Min, Su. Jung, 1997. Constructing ideology: A critical linguistic analysis. Studies in the Linguistic Science. 27(2), 147-165.

O’ Halloran, Kieran. 2003. Critical discourse analysis and language cognition. Edinburg University Press.

Ojo and Adebayo, 2013. Many 'sins' of the mass media in Nigeria: A critical appraisal of the media in a decade of nascent democracy. Journal of media and communication studies,5(8), pp. 95-102.

Osunsanwo, Ayo. 2016. Role allocation in the media representation of participants in selected electoral discourses in Nigeria. Athens Journal of Mass Media and Communications, 2(3), 183-204.

Post, Michael David. 2009. Representations of meaning within textual personas: An analysis of 2008 US presidential campaign speeches. University of Birmingham. M.A Thesis.

Rashidi, Nasser and Rasti Alireza. 2012. Doing (in) justice to Iran's Nuke Activities? A critical discourse analysis of news reports of four western quality newspapers. American Journal of Linguistics, 1(1), 1-9

Sahragard, Rahman and Davatgarzadeh, G. 2010. The representation of social actors in interchange third edition series: A critical discourse analysis. The Journal of Teaching Language Skills (JTLS) 2(1), 67-89. 
Susan Strauss, Parastou Feiz. 2014. Discourse Analysis: Putting our worlds into words. New York: Routledge.

van Dijk, Teun. A. 1993. Principles of critical discourse analysis. Discourse \& Society, 4(2), 249-283.

van Dijk, Teun. A. 2006. Ideology and discourse analysis. Journal of Political Ideologies, 11(2), 115-140.

Wang, Junling. 2010. A critical discourse analysis of Barack Obama's speeches. Journal of Language Teaching and Research, 1(3), 254-261.

Wodak, Ruth. \& Meyer, Michael. eds., 2001. Methods of Critical Discourse Analysis: Introducing Qualitative Methods. London: Sage.

Zhuanglin, Hu. 1988. A course of linguistics. Peking: Peking University Press. 